\title{
Media Pembelajaran Matematika Bilingual Berbasis Sparkol Videoscribe
}

\author{
Dwi Fadila Rahmatika ${ }^{*}$, Nining Ratnasari ${ }^{2}$ \\ ${ }^{1}$ Universitas Islam Negeri Raden Intan Lampung. Jalan Endro Suratmin, Sukarame, Bandar \\ Lampung 35133, Indonesia. \\ 2Bimbingan Belajar Suryaprima Lampung. Jalan RA. Basyid No. 80 A-C Fajar Baru 2, Jati Agung, \\ Lampung Selatan, Indonesia \\ *Corresponding Author. E-mail: nisaamelia66@yahoo.com
}

Received : 13-08-2018; Revised : 19-09-2018; Accepted : 30-09-2018

\begin{abstract}
Abstrak
Penelitian dan pengembangan ini bertujuan untuk mengetahui kelayakan, kemenarikan respon mahasiswa, dan keefektifan terhadap pengembangan media pembelajaran bilingual berbasis sparkol videoscribe. Jenis penelitian dalam pengembangan ini adalah (Research and Development). Adapun model pengembangan yang digunakan yaitu, model ADDIE dengan lima langkah penelitian; Analisis (Analyse), perencanaan (Design), pengembangan (Development), Implementasi (Implementation), dan Evaluasi (Evaluation). Teknik pengumpulan data dengan menggunakan lembar angket dan tes. Instrumen yang digunakan berupa lembar angket untuk mengetahui kelayakan dan kemenarikan respon peserta didik, serta tes untuk mengetahui keefektifan produk hasil pengembangan. Teknik analisis data yang digunakan yaitu, deskriptif kuantitatif dan deskriptif kualitatif. Diperoleh hasil rata-rata uji kelayakan terhadap media pembelajaran oleh ahli media, ahli materi, dan ahli bahasa dengan krteria "sangat baik (SB)". Hasil rata-rata uji kemenarikan terhadap respon mahasiswa dengan kriteria "sangat baik (SB)". Dapat disimpulkan bahwa produk pengembangan media pembelajaran bilingual berbasis sparkol videoscribe yang dihasilkan adalah layak, menarik, dan efektif dengan memberikan hasil yang baik dalam implementasinya.
\end{abstract}

Kata Kunci. Media Pembelajaran, Bilingual, Sparkol Videoscribe, Logika Matematika

\begin{abstract}
This research and development aims to determine the feasibility, attractiveness of student responses, and the effectiveness of the development of videoscribe sparkol-based bilingual learning media. The type of research in this development is (Research and Development). The development model used is the ADDIE model with five research steps; Analysis (Analyze), planning (Design), development (Development), Implementation (Implementation), and Evaluation (Evaluation). Data collection techniques using questionnaire sheets and tests. The instrument used was in the form of a questionnaire to determine the feasibility and attractiveness of students' responses, as well as tests to determine the effectiveness of the products developed. Data analysis techniques used are quantitative descriptive and qualitative descriptive. Obtained the results of the average feasibility test for learning media by media experts, material experts, and linguists with a "very good (SB)". The results of the average attractiveness test on the response of students with the criteria "very good $(S B)$ ". It can be concluded that the product development of the generated videocribe sparkol bilingual learning media is feasible, interesting, and effective by providing good results in its implementation.
\end{abstract}

Keyword:. Learning Media, Bilingual, Sparkol Videoscribe, Mathematical Logic 


\section{PENDAHULUAN}

Pentingnya media sebagai sarana pendukung pembelajaran di kelas. Media berperan sebagai alat bantu memvisualisasikan materi yang abstrak menjadi konkret serta untuk mengatasi keterbatasan pengalaman yang dimiliki oleh mahasiswa (Triastuti, Akbar, dan Irawan 2017). Khususnya pada mata kuliah logika matematika tingkat perguruan tinggi. Logika matematika merupakan salah satu mata kuliah yang harus dikuasi oleh mahasiswa (Rudhito dan Susento 2012). Namun pada kenyataannya, masih banyak mahasiswa yang menemukan kendala pada mata kuliah tersebut. Adapun kendala tersebut yaitu, mahasiswa masih mengalami kesulitan dalam memahami materi maupun pengerjaan tugas berupa soalsoal latihan yang diberikan oleh dosen pengampu. Selain itu juga penggunaan media pembelajaran berupa buku teks sebagai satu-satunya sumber belajar dirasa masih kurang efektif dalam membantu mahasiswa dalam melatih kemampuan pemecahan masahahnya (Masykur, Nofrizal, dan Syazali 2017; Putra 2017). Berdasarkan hal tersebut, maka diperlukan adanya sebuah media pembelajaran tambahan sebagai alat bantu dalam proses pembelajaran (Anjana 2013). Agar memberikan kemudahan bagi mahasiswa dalam mengampu mata kuliah logika matematika tersebut.

Pemilihan media untuk keperluan pembelajaran haruslah relevan dan sesuai dengan karakteristik maupun kebutuhan mahasiswa. Ditambah dengan perkembangan teknologi saat ini, maka dalam membuat media pembelajaran haruslah terus disesuaikan dengan perkembangan dari waktu kewaktu (Ashfahany, Adi, dan Hariyanto 2017). Contohnya saja penggunaan teknologi, yang berbasiskan penggunaan teknologi komputer, menjadi suatu upaya yang diutamakan demi kemajuan suatu perguruan tinggi. Sejalan dengan upaya pemerintah dalam meningkatkan kualitas mutu pendidikan dalam bidang matematika dicanangkan pula sebuah konsep pendidikan bertaraf internasional yang diharapkan output-nya dapat bersaing di dunia internasional. Adapun yang mendasari konsep pendidikan bertafar internasional adalah sebagaimana tertuang dalam Undangundang No. 20 tahun 2003 pasal 50 ayat 3 (Setiwan 2008; Setyosari 2013; Triastari 2011). Berdasarkan hal tersebut, dengan berbagai upaya yang dilakukan pemerintah dalam memicu banyak lembaga pendidikan untuk meningkatkan kualitas sistem pendidikannya, adalah dengan cara diterapkannya sistem bilingual pada mata pelajaran atau mata kuliah (Triastari 2011). Sehingga dengan dikembangkannya sebuah media pembelajaran bilingual dengan teknologi komputer, sangat membantu mahasiswa dalam memahami mata kuliah logika matematika yang abstrak. Penggunaan media pembelajaran berbasis komputer dengan audio visual ternyata memberikan hasil yang baik terhadap pemahaman konsep mahasiswa terhadap materi yang dipelajari (Sardiman Arief 2011). Sebagai media pembelajaran, penggunaan komputer dapat mendeskripsikan dengan baik hal-hal yang abstrak dalam matematika (Wahyudi 2012; Setiwan 2008).

Pengembangan media pembelajaran bilingual yang dimaksudkan adalah dengan berbasiskan sparkol videoscribe. Selain itu dalam pengolahannya, komputer juga mampu menyediakan fitur audio visual yang sangat dibutuhkan pada proses pembelajaran untuk dapat belajar matematika secara mandiri dan 
prosedural. Sparkol videoscribe merupakan sebuah media pembelajaran video animasi yang terdiri dari rangkaian gambar yang disusun menjadi sebuah video utuh. Karakteristik penggunaan sparkol videoscribe yang unik, dengan mampu menyajikan konten pembelajaran dengan memadukan gambar, suara, dan desain yang menarik sehingga mahasiswa mampu menikmati proses pembelajaran (Octavianingrum 2016; Safitri 2017; Sunarni 2016).

Berdasarkan dari hasil penelitianpenelitian terdahulu yang sudah dilakukan peneliti sebelumnya, penggunaan pengembangan media pembelajaran berbasiskan sparkol videoscribe memberikan dampak yang baik dalam proses pembelajaran (Dwi Pratiwi 2017; Yusup, Aini, dan Pertiwi 2016; Sunarni 2016). Adapun keterbaruan dalam penelitian ini dengan penelitian sebelumnya terletak pada, konsep bilingual yang dihadirkan yakni sebagai bahasa pengantar yaitu, bahasa indonesia dan bahasa inggris pada mata kuliah logika matematika di tingkat perguruan tinggi. Penelitian dan pengembangan yang dilakukan untuk mengetahui kelayakan, kemenarikan respon mahasiswa, dan keefektifan terhadap pengembangan media pembelajaran bilingual berbasis sparkol videoscribe, sehingga dapat dihasilkan produk yang layak, menarik, dan efektif dengan memberikan hasil yang baik dalam implementasinya.

\section{METODE}

Jenis penelitian dalam pengembangan ini adalah (Research and Development). Adapun model pengembangan yang digunakan yaitu, model ADDIE dengan lima langkah penelitian; Analisis (Analyse), perencanaan (Design), pengembangan (Development), Implementasi (Implementation), dan Evaluasi (Evaluation) (made tegeh, nyoman jampel, dan pudjawan 2014). Teknik pengumpulan data dengan menggunakan lembar angket dan tes. Instrumen yang digunakan berupa lembar angket untuk mengetahui kelayakan dan kemenarikan respon mahsiswa, serta tes untuk mengetahui keefektifan produk hasil pengembangan. Secara umum prosedur penelitian dan pengembangan dapat dilihat pada Gambar 1.

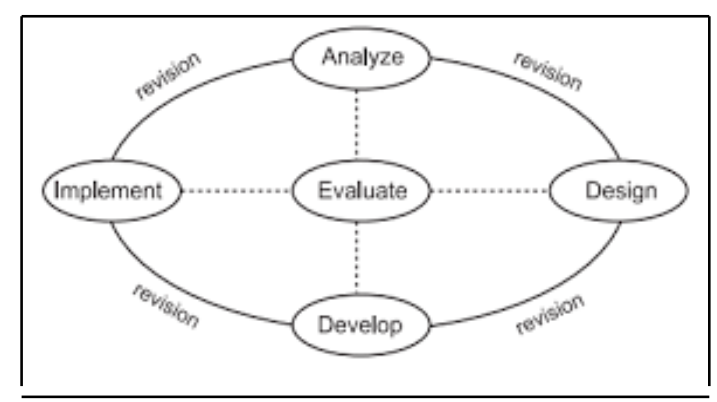

Gambar 1. Prosedur Penelitian dan Pengembangan dengan Model ADDIE

Berdasarkan pada Gambar 1 tersebut, tahapan ADDIE meliputi:

1) Analyze, yaitu melakukan observasi dan wawancara pada peserta didik dan pendidik atau pengajar.

2) Design, yaitu melakukan perancangan mengenai media yang akan dibuat termasuk mempersiapkan materi dan segala hal yang berkaitan dengan pembuatan media.

3) Develop, yaitu pembuatan media pembelajaran dengan penilaian yang dilakukan oleh validator, serta revisi perbaikan produk.

4) Implement, yaitu produk diujikan pada kelas kecil yakni sebanyak 10 orang dan kelas besar sebanyak 26 orang, selanjutnya, pada kelas besar dilakukan eksperimentasi dengan membandingkan kelas besar dengan kelas kecil (tanpa disajikan media pembelajaran) untuk melihat adakah perbedaan dari penggunaan produk yang dihasilkan.

5) Evaluate, yaitu pengevaluasian dilakukan pada setiap tahapan 
Desimal, 1 (3), 2018 - 388

Dwi Fadila Rahmatika, Fredi Ganda Putra

dilakukan disetiap tahapan (Metode Penelitian Pendidikan, n.d.).

Teknik analisis data yang digunakan yaitu, deskriptif kuantitatif dan deskriptif kualitatif. Data kualitatif berupa komentar dan saran, sedangkan data kuantitatif berupa nilai rentangan skala. Langkahlangkah dalam menganalisis data instrumen validasi oleh para ahli validator untuk mengetahui kelayakan adalah sebagaimana pada Tabel 1.

\begin{tabular}{lc}
\multicolumn{2}{c}{\begin{tabular}{c} 
Tabel 1. Pedoman Skor Penilaian Para \\
\multicolumn{2}{c}{ Ahli Validator (Anjana 2013) }
\end{tabular}} \\
\hline \multicolumn{1}{|c}{ Kriteria } & Skor \\
Sangat Baik (SB) & 4 \\
Cukup Baik (CB) & 3 \\
Tidak Baik (TB) & 2 \\
Sangat Tidak Baik (STB) & 1 \\
\hline
\end{tabular}

Hasil validasi yang tertera dalam lembar validasi terhadap media akan dicari rata-rata penilai validator (oleh ahli materi, ahli media, dan ahli bahasa) dengan menggunakan rumus sebagai berikut:

$P$

$=\frac{\text { Jumlah skor hasil pengumpulan data }}{\text { jumlah skor kriterium }}$
$\times 100 \%$

Keterangan :

$P=$ angka persentase data angket

Kemudian, hasil dari presentase validasi media tersebut dapat dikelompokkan dalam kriteria interpretasi kelayakan skor menurut skala likert sehingga akan diperoleh kelayakan sebagai suatu hasil. Kriteria layak di dapatkan jika mencapai standar cukup baik. Kriteria interpretasi kelayakan validator dapat dilihat pada Tabel 2 .

Tabel 2. Range Persentase Kriteria Kualitatif Program Kelayakan

\begin{tabular}{c|c}
\hline Persentase $(\boldsymbol{P})$ & Kriteria \\
$75 \% \leq \mathrm{P} \leq 100 \%$ & Sangat Baik \\
$50 \% \leq \mathrm{P}<75 \%$ & Cukup Baik \\
$25 \% \leq \mathrm{P}<50 \%$ & Tidak Baik \\
$0 \% \leq \mathrm{P}<25 \%$ & Sangat Tidak Baik \\
\hline
\end{tabular}

Sedangkan angket yang diberikan kepada mahasiswa di bagikan setelah dilakukan uji coba media pembelajaran bilingual berbasis sparkol videoscribe, dengan tujuan untuk mengetahui respon mahasiswa terhadap pengembangan produk media pembelajaran selama mengikuti proses pembelajaran berlangsung. Berikut ini langkah-langkah dalam menganalisis data instrumen validasi oleh para ahli validator untuk mengetahui kemenarikan adalah sebagaimana pada Tabel 3.

Tabel 3. Pedoman Skor Penilaian Respon Mahasiswa

\begin{tabular}{cc}
\hline Kriteria & Skor \\
\hline Sangat Setuju (SS) & 4 \\
Cukup Setuju (CS) & 3 \\
Tidak Setuju (TS) & 2 \\
Sangat Tidak Setuju (STS) & 1 \\
\hline
\end{tabular}

Selanjutnya dilakukan perhitungan setiap butirnya yakni sebagai berikut:

$$
\begin{aligned}
& P \\
& =\frac{\text { Jumlahskor hasil pengumpulan data }}{\text { jumlah skor kriterium }} \\
& \times 100 \%
\end{aligned}
$$

Keterangan :

$P=$ angka persentase data angket

Kemudian, hasil dari presentase validasi media tersebut dapat dikelompokkan dalam kriteria interpretasi kemenarikan skor menurut skala likert sehingga akan diperoleh kemenarikan sebagai suatu hasil. Kriteria menarik di dapatkan jika mencapai standar cukup baik. Kriteria interpretasi kemenarikan validator dapat dilihat pada Tabel 4. 
Tabel 4. Range Persentase Kriteria Kualitatif Program Kemenarikan Persentase $(P)$ Kriteria

$75 \% \leq \mathrm{P} \leq 100 \%$ Sangat Baik

$50 \% \leq \mathrm{P}<75 \%$ Cukup Baik

$25 \% \leq \mathrm{P}<50 \%$ Tidak Baik

$0 \% \leq \mathrm{P}<25 \%$ Sangat Tidak Baik

Langkah yang sama dilakukan untuk mendapatkan hasil respon mahasiswa terhadap produk pengembangan media pembelajaran diberikan setelah pembelajaran dengan menggunakan media berbasis sparkol videoscribe berdasarkan angket yang telah diberikan.

\section{HASIL DAN PEMBAHASAN}

Produk pengembangan berupa media pembelajaran bilingual berbasis sparkol videoscribe. Adanya informasi awal yang dijadikan panduan dalam mendesain produk awal media pengembangan, yang disesuaikan dengan karakteristik kebutuhan mahasiswa. Tahapan yang digunakan dalam penelitian dan pengembangan ini 5 tahapan yang ada. Adapun hasil penelitian dan pengembangan dalam penelitian ini berdasarkan 5 tahapan Model ADDIE, di uraikan dan dijelaskan meliputi:

a. Analysis

Tahap analisis meliputi analisis kebutuhan mahasiswa yang akan membantu dalam mengetahui kendala dan kebutuhan mahasiswa dalam pembelajaran Evaluasi Hasil Belajar Logika Matematika.

b. Design.

Tahap desain ini meliputi (1) perancangan media, (2) perancangan instrumen penilaian lembar validasi, baik validasi untuk validator ahli materi, ahli media, dan ahli bahasa serta (3) perancangan quesioner penilaian respon mahasiswa terhadap pengembangan media pembelajaran.

c. Development

Pada tahap pengembangan dilakukan validasi produk dan revisi produk.

Hasil penelitian didapatkan berdasarkan cakupan hasil penilaian dari para validator, responden dan pemaparan hasil eksperimentasi peneliti. Pada tahap validasi, dilakukan penilaian dari masing-masing ahli validator yang diperoleh data meliputi:

Tabel 5. Hasil Validator Ahli Materi

\begin{tabular}{|c|c|c|c|}
\hline No & Aspek & Presentase & Kriteria \\
\hline 1 & Kelayakan Isi & $77 \%$ & Sangat Baik (SB) \\
\hline 2 & $\begin{array}{l}\text { Kelayakan } \\
\text { Penyajian }\end{array}$ & $79 \%$ & Sangat Baik (SB) \\
\hline 3 & Keterlaksanaan & $83 \%$ & Sangat Baik (SB) \\
\hline
\end{tabular}

Berdasarkan pada Tabel 5 tersebut adalah menunjukkan hasil dari penilaian validator ahli materi. Diperoleh pada aspek kelayakan isi dengan presentase sebesar $77 \%$ dalam kriteria sangat baik (SB), pada aspek kelayakan penyajian sebesar $79 \%$ dalam kriteria sangat baik (SB) dan pada aspek keterlaksanaan sebesar 83\% dalam kriteria sangat baik (SB). Hasil sebagaiamana pada Tabel 5, diperoleh setelah dilakukannya revisi perbaikan produk sesuai dengan kritik dan saran dari validator. Adapun hasil 
Desimal, 1 (3), 2018 - 390

Dwi Fadila Rahmatika, Fredi Ganda Putra

tabel yang berisi hasil terhadap media oleh validator ahli media yakni sebagaimana pada Tabel 6 .

Tabel 6. Hasil Validator Ahli Media

\begin{tabular}{cccc} 
No & Aspek & Presentase & Kriteria \\
1 & Kualitas Video & $83 \%$ & Sangat Baik (SB) \\
2 & Desain Video & $83 \%$ & Sangat Baik (SB) \\
3 & Tampilan Video & $95 \%$ & Sangat Baik (SB) \\
\hline
\end{tabular}

Berdasarkan pada Tabel 6 tersebut adalah menunjukkan hasil dari penilaian validator ahli media. Diperoleh pada aspek kualitas video dengan presentase sebesar $83 \%$ dalam kriteria sangat baik (SB), pada aspek desain video sebesar 79\% dalam kriteria sangat baik (SB) dan pada aspek tampilan video $83 \%$ dalam kriteria sangat baik (SB).

Tabel 7. Hasil Validator Ahli Bahasa

\begin{tabular}{|c|c|c|c|}
\hline No & Aspek & Presentase & Kriteria \\
\hline 1 & Lugas & $75 \%$ & Sangat Baik (SB) \\
\hline 2 & Komunikatif & $100 \%$ & Sangat Baik (SB) \\
\hline 3 & Dialogis dan Interaktif & $75 \%$ & Sangat Baik (SB) \\
\hline 4 & Kesesuaian dengan Perkembangan Mahasiswa & $75 \%$ & Sangat Baik (SB) \\
\hline 5 & Kesesuaian dengan Kaidah Bahasa & $88 \%$ & Sangat Baik (SB) \\
\hline
\end{tabular}

Berdasarkan pada Tabel 7 tersebut adalah menunjukkan hasil dari penilaian validator ahli bahasa. Diperoleh pada aspek lugas dengan presentase sebesar $75 \%$ dalam kriteria sangat baik (SB), pada aspek komunikatif sebesar $100 \%$ dalam kriteria sangat baik (SB), pada aspek dialogis dan interaktif sebesar $75 \%$ dalam kriteria sangat baik (SB), pada aspek kesesuaian dengan perkembangan mahasiswa sebesar 75\% dalam kriteria sangat baik (SB), dan pada aspek kesesuaian dengan kaidah bahasa sebesar $88 \%$ dalam kriteria sangat baik (SB).

Selaian penilaian dari validator, peneliti juga melakukan uji coba kelas kecil dan kelas untuk mengetahui
Hasil tersebut diperoleh setelah dilakukan revisi perbaikan terhadap produk sesuai kritik dan saran dari validator, sehingga produk yang dikembangkan jauh lebih layak dari sebelumnya. Selanjutnya hasil penilaian dari validator ahli bahasa yang dapat dilihat pada Tabel 7 . 
Desimal, 1 (3), 2018 - 391

Dwi Fadila Rahmatika, Fredi Ganda Putra

penggunaan media pembelajaran pada hasil belajar mahasiswa. Ekeperimentasi dilakukan dengan uji parametris yaitu uji $T$. Sebelum melakukan uji $T$ terlebih dahulu dilakukan uji asumsi diantaranya: uji normalitas dan homogenitas. Uji normalitas untuk mengetahui apakah sebaran data berdistribusi normal atau tidak dan uji homogenitas untuk mengetahui sama tidaknya variansi dua buah distribusi data. Adapun hasil data uji normalitas dapat dilihat pada Tabel 8.

Tabel 8. Hasil Uji Homogenitas dan Normalitas

\section{Test of Homogeneity of Variances}

Nilai Posttest

Levene Statistic df1 df2 Sig.

$\begin{array}{llll}1.236 & 1 & 50 & .272\end{array}$

Uji diatas ialah uji homogenitas, uji ini dilakukan untuk mengetahui apakah kedua kelas tersebut homogen (tidak ada perbedaan yang signifikan)Homogenitas pada penelitian ini didapatkan hasil taraf signifikannya $0,272>0,05$, hal ini berarti kedua kelas tersebut adalah homogen. Sehingga dapat disimpulkan bahwa kedua kelas tersebut dapat dibandingkan.

Selanjutnya dilakukan uji normalitas uji normalitas adalah suatu pengujian yangdilakukan untuk mengetahui apakah suatu variabel normal atau tidak. Normal berarti mempunyai distribusi data yang normal. Jika suatu data berdistribusi normal, maka uji-T dapat dilakukan. Hasil pengujian nilai posttest tersebut dapat dilihat sebagaimana pada Tabel 9.

Tabel 9. Hasil Uji Normalitas

One-Sample Kolmogorov-Smirnov Test

\begin{tabular}{|c|c|c|}
\hline \multicolumn{3}{|c|}{ One-Sample Kolmogorov-Smirnov Test } \\
\hline & & Unstandardized Residual \\
\hline \multicolumn{3}{|l|}{$\mathrm{N}$} \\
\hline \multirow[t]{2}{*}{ Normal Parameters ${ }^{a}$} & Mean & .0000000 \\
\hline & Std. Deviation & 7.25043186 \\
\hline \multirow{3}{*}{$\begin{array}{l}\text { Most Extreme } \\
\text { Differences }\end{array}$} & Absolute & .160 \\
\hline & Positive & .110 \\
\hline & Negative & -.160 \\
\hline \multicolumn{2}{|c|}{ Kolmogorov-Smirnov Z } & .814 \\
\hline \multicolumn{2}{|l|}{ Asymp. Sig. (2-tailed) } & .522 \\
\hline
\end{tabular}

Berdasarkan hasil uji normalitas tersebut diketahui nilai signifikannya 0,552 > 0,05 maka dapat disimpulkan bahwa nilai residual berbdistribusi normal sehingga dapat dilakukan uji-T.

Langkah selanjutnya dilakukan lah uji-T. Uji-T dilakukan setelah data berdistribusi normal. Uji-T dilakukan untuk mengetahui adakah pengaruh penggununaan media pembelajaran dengan hasil belajar peserta didik yang dilakukan dikelas eksperimen (kelas besar/kelas yang disajikan media pembelajaran). 
Desimal, 1 (3), 2018 - 392

Dwi Fadila Rahmatika, Fredi Ganda Putra

Tabel 10. Uji t

\begin{tabular}{llcccccc} 
& & \multicolumn{3}{c}{$\begin{array}{c}\text { Lavene's Test for } \\
\text { Equality of Variances }\end{array}$} & \multicolumn{4}{c}{ t-test for Equality of Means } \\
Hasil & F & Sig. & T & df & Sig. (2 tailed) & Mean \\
Belajar & $\begin{array}{l}\text { Equal variances } \\
\text { assumed }\end{array}$ & 1.236 & 0.272 & -3.091 & 50 & 0.003 & 73.7692 \\
& & & & & & \\
& $\begin{array}{l}\text { Equal variances } \\
\text { not assumed }\end{array}$ & & & -3.091 & 49.791 & 0.003 & 80.5769 \\
\hline
\end{tabular}

Berdasarkan Tabel 10, diperoleh taraf signifikansi sebesar 0,003 0,005 yang berarti adanya pengaruh media pembelajaran terhadap hasil belajar peserta didik. Pada tabel tersebut juga diketahui nilai rata-rata kelas eksperimen sebesar 80,57 lebih baik dari rata-rata kelas kontrol yakni sebesar 73,76.

\section{e. Evaluate}

Tahap Evaluasi merupakan proses yang dilakukan untuk memberikan penilaian. Sebagaimana terdapat perbedaan hasil belajar yang signifikan antara kelas eksperimen dan kelas kontrol. Hal ini menunjukkan bahwa produk pengembangan bahan ajar matematika berupa media pembelajaran bilingual berbasis sparkol videoscribe pada materi logika matematika dapat meningkatkan hasil belajar mahasiswa. Diperoleh hasil rata-rata uji kelayakan terhadap media pembelajaran oleh ahli media, ahli materi, dan ahli bahasa dengan krteria "sangat baik (SB)". Hasil rata-rata uji kemenarikan terhadap respon mahasiswa dengan kriteria "sangat baik (SB)". Dapat disimpulkan bahwa produk pengembangan media pembelajaran bilingual berbasis sparkol videoscribe yang dihasilkan adalah layak, menarik, dan efektif dengan memberikan hasil yang baik dalam implementasinya.

\section{SIMPULAN DAN SARAN}

Berdasarkan hasil analisis dan pengolahan data yang didukung dengan landasan teori serta mengacu pada tujuan penelitian, maka dapat disimpulkan bahwa: Diperoleh hasil rata-rata uji kelayakan terhadap media pembelajaran oleh ahli media, ahli materi, dan ahli bahasa dengan krteria "sangat baik (SB)". Hasil rata-rata uji kemenarikan terhadap respon mahasiswa dengan kriteria "sangat baik (SB)". Dapat disimpulkan bahwa produk pengembangan media pembelajaran bilingual berbasis sparkol videoscribe yang dihasilkan adalah layak, menarik, dan efektif dengan memberikan hasil yang baik dalam implementasinya.

Berdasarkan kesimpulan di atas terdapat beberapa saran yang dapat dilakukan pada pengembangan media pembelajaran bilingual berbasis sparkol videoscribe pada materi logika matematika meliputi diantaranya: pembuatan media pembelajaran bilingual berbasis sparkol videoscribe tidak hanya menyajikan materi logika matematika saja sehingga diharapkan untuk dapat mengembangkan materi lainnya dengan software yang sama. Selain itu media pembelajaran bilingual berbasis sparkol videoscribe pada materi logika 
matematika masih terdapat banyak kekurangan sehingga pengembangan media selanjutnya dapat dikembangkan menjadi media pembelajaran yang lebih baik, agar dapat menambah minat dan semangat mahasiswa dalam mempelajari materi yang diajarkan serta dapat digunakan disegala perguruan tinggi.

\section{DAFTAR PUSTAKA}

Anjana, Nitro. 2013. "Pengembangan Media Presentasi Teknik Digital sebagai Penunjang Mata Diktat Teknik Mikroposesor untuk SMK N 7 Surabaya." Jurnal Pendidikan Teknik Elektro, no. 3.

Ashfahany, Fahmi Arif, Sapto Adi, dan Eko Hariyanto. 2017. "Bahan Ajar Mata Pelajaran Pendidikan Bentuk Multimedia Interaktif Untuk Siswa Kelas VII." Jurnal Pendidikan: Teori, Penelitian, dan Pengembangan 2 (2): 261-267.

Dwi Pratiwi, Erlia. 2017. "Pengembangan Media Pembelajaran Berbasis Sparkol Videoscribe Pokok Bahasan Kinematika Gerak di Perguruan Tinggi." Universitas Islam Negeri Raden Intan Lampung, 6.

Made tegeh, i, i nyoman jampel, dan i pudjawan. 2014. model penelitian pengembangan. yogyakarta: Graha Ilmu.

Masykur, Rubhan, Nofrizal Nofrizal, dan Muhamad Syazali. 2017. "Pengembangan Media Pembelajaran Matematika Dengan Macromedia Flash." Al-Jabar : Jurnal Pendidikan Matematika 8 (2): 17786.

Metode Penelitian Pendidikan. n.d. Bandung: ALFABETA.

Octavianingrum, Dilla. 2016. "Pengembangan Media Audio Visual Sparkol dalam Pembelajaran Mengelola Rapat Pertemuan Di LLP IPMI Kusuma bangsa Surakarta." Junal Perpustakaan UNS, 33.

Putra, Fredi Ganda. 2017. "Eksperimentasi Pendekatan Kontekstual Berbantuan
Hands On Activity (HoA) Terhadap Kemampuan Pemecahan Masalah Matematik." Al-Jabar: Jurnal Pendidikan Matematika 8 (1): 73-80. Rudhito, M. Andy, dan Susento. 2012. "Tingkat-Tingkat Berpikir Mahasiswa dalam Menerjemahkan Pernyataan Matematis Berkuantor Universal dari Bentuk Kalimat Biasa Menjadi Bentuk Kalimat Formal" 5 (1): 13-24.

Safitri, Sani. 2017. "Pengembangan Media Pembelajaran Menggunakan Program Videoscribe Sparkol pada Mata Pelajaran Sejarah kelas XI di Sekolah Menengah Atas." Criksetra: Jurnal Pendidikan Sejarah dan Ilmu Sejarah 6 (1).

Sardiman Arief, S. 2011. Media Pendidikan: Pengertian, Pengembangan, dan Pemanfaatannya. Jakarta: Rajawali Pers.

Setiwan, Denny. 2008. Komputer dan Media Pembelajaran. Jakarta: Universitas Terbuka.

Setyosari, Pujiani. 2013. Metode Penelitian Pendidikan dan Pengembangan. Jakarta: Kencana.

Sunarni, Sri. 2016. "Pengembangan Media Pembelajaran Power Point Berbasis Sparkol Pada Pokok Bahasan Perumusan Dasar Negara Pada Mata Pelajaran PKN." Jurnal Penelitian dan Pendidikan IPS 10 (3): 363-372.

Triastari, Astrid. 2011. Strategi Mengajar Bilingual. Surabaya: Cerdas Pustaka.

Triastuti, Desty, Sa'dun Akbar, dan Edy Bambang Irawan. 2017. "Pengembangan Media Papan Permainan Panjat Pinang." Jurnal Pendidikan: Teori, Penelitian, dan Pengembangan 2 (10): 1344-1350.

Wahyudi, Arif. 2012. "Penggunaan Media Audio Visual Dalam Peningkatan Hasil Belajar Matematika." Kalam Cendekia PGSD Kebumen 1 (2).

Yusup, Muhamad, Qurotul Aini, dan Komala Dwi Pertiwi. 2016. "Media Audio Visual Menggunakan 
Desimal, 1 (3), 2018 - 394

Dwi Fadila Rahmatika, Fredi Ganda Putra

Videoscribe Sebagai Penyajian Informasi Pembelajaran Pada Kelas

Sistem Operasi." Technomedia Journal 1 (1): 126-139. 